\title{
2. THE PARODY MASS AND THE RETHORICAL-PEDAGOGICAL PRINCIPLE OF IMITATION
}

\author{
Rossella Marisi
}

\begin{abstract}
In the sixteenth century, composing a parody Mass was a means to pay tribute to an admired piece and master the composing techniques shown therein. The parody Mass is grounded on the principles of imitation and emulation, on which the whole Renaissance rhetoric is based. This article analyses the Missa Quem dicunt homines by Palestrina. It stresses that in the Renaissance a musician could choose to compose a parody Mass, instead of a Mass on cantus firmus, not only to go towards the taste of his clients, and to suit his own preferences, but also to adhere to a certain rhetorical-pedagogical school of thought.
\end{abstract}

Key words: imitative-style Motet, Palestrina, poetry, Renaissance, visual arts

\section{Imitation as a pedagogical tool}

The term pedagogy indicates "sets of teaching and learning practices that shape the interaction between teachers and learners" (Peterson, 2018: 8). Since students may have different emotions, personalities and cognitive capacities, and may diverge in their interests, motivations, and approaches to learning (Dumont, 2018), teachers may choose different pedagogical approaches grounded in different theories of learning. Indeed, since hundreds of years experts share the view that a successful education depends to a large extent from the teacher's adoption of appropriate teaching methods (Zielonka, 2019). In the musical area, musicians in formation may find some obstacles to overcome: composers my suffer from a composer's block, finding it difficult to compose a whole piece, and performers may be uncertain of how to produce an expressive performance of a piece, hesitating to adopt microvariations in timing, intensity, articulation, and pedaling, appropriate to the piece's historical period and style.

In such cases, an effective chance is given by observational learning, a concept introduced by Albert Bandura and Robert Jeffrey in 1973. They described this process as based on some components, among which the first are attention, retention and reproduction (Bandura and Jeffrey, 1973). Also Russell espouses the opinion that studying a wide variety of works helps the student to identify the best qualities of the proposed models, acquiring in this way a sharp judgement, retain the most important peculiarities of each model, and use them as tools in the composition of original works (Russell, 1979).

Indeed, in recent years some experts highlighted that imitation plays a large role in learning and generally in socialization. In the words of Frank Smith: "Infants not only learn to talk like the kind of people they see themselves as being; they also learn to walk like them, dress like them, groom and ornament themselves like them, eat and drink like them. They learn to perceive the world in the way the people around them perceive it, and to share their hopes and fears, their beliefs and expectations, their imperatives and values. They learn a culture" (Smith, 1986:

${ }^{3}$ Lecturer PhD., Conservatorio "Lorenzo Perosi” from Campobasso, Accademia di Belle Arti from Bologna, Italy, email: rossellamarisi@ hotmail.it 
40). In a similar vein, Mary Oliver stated: "You would learn very little in this world if you were not allowed to imitate. And to repeat your imitations until some solid grounding in the skill was achieved and the slight but wonderful differences - that made you you and no one else - could assert itself" (Oliver, 1994: 13).

The statements made concerning the appropriation of culture and the development of poetry apply in the same way also to musical composition and performance. On the one hand it is a common belief that musicians and visual artists, such as painters and sculptors, have particular talents for their own, which are innate and cannot be acquired in school. On the other hand, it is also wellknown that visual artists and musicians can develop their talents to their full potential through an acquaintance with the specific theories and techniques characterizing their particular artistic field (Oliver, 1994), and that this knowledge can mainly be acquired attending research and teaching institutions such as academies of arts and music conservatories.

Teachers in this kind of institutions often demonstrate how a certain artwork should be created or interpreted, and students imitate their gestures and procedures, in order to familiarize themselves with the employed techniques and gradually master their core requirements. According to the same view, in the sixteenth century many composers included pre-existent music in their compositions. The borrowed music could be simply transcribed from vocal pieces to instrumental ones, such as in tablatures, or a section of the earlier piece could be integrated in a newly written one, or its text could be substituted for a new one, such as in contrafacta.

\section{The parody Mass, or Missa ad imitationem}

In the sixteenth century, one of the most common types of Mass was the cyclic Mass, "in which a single melodic or multi-voice 'theme' cuts across and thus unifies all five liturgical 'movements' [of the Mass Ordinary]: Kyrie, Gloria, Credo, Sanctus, and Agnus Dei" (Atlas, 2006: 101). When a cyclic Mass used the same motivic construction of its model and quoted two or more of its voices, it was called a parody Mass. This term was firstly used in 1587 by the German composer Jacob Paix, who composed a Mass based on a Motet by Thomas Crecquillon. Publishing his work, Paix entitled it Missa Parodia mottetce Domine da nobis auxilium, understanding the term parodia as synonymous with the Latin expression ad imitationem (Atlas, 2006).

The parody Mass offered an almost unlimited number of creative possibilities to the composer, and we know from the sixteenth-century treatises that copying their master's compositions was an integral part of the composer-information's path (Günther, 1986; Mayer Brown 1986). It is important to remind that in this kind of composition not just a few motives, but an entire pre-existent piece was reworked and developed. Unfortunately, although parody Masses were the favorite genre of a number of musicians in the sixteenth century, very few theorists described in detail the composition technique of a Missa ad imitationem. In order to give some hints on the way composers wrote a parody Mass on a Motet, I will highlight the structure of the imitative-style Motet, a type which was very common around 1500 (Lockwood, 1964). 
The text of the Motet can be divided into sections, each corresponding to a verse. Each verse can be set to music with one or more motives: each of them is sung by all the voices, as imitation or in a homorhythmic texture.

One example thereof is Jean Richafort's four-voice Motet Quem dicunt homines, published in 1508. Many composers found it a suitable model for the composition of parody Masses. The text of the Motet refers to Jesus's words in Matthew 16:13 and 16-18, John 21:15 and 17, 13:37, and Luke 22:32.

\begin{tabular}{|c|c|}
\hline Latin text & English translation \\
\hline $\begin{array}{l}\text { Quem dicunt hómines esse Fílium } \\
\text { hóminis? } \\
\text { Respóndens Petrus dixit: } \\
\text { Tu es Christus, Fílius Deus vivi } \\
\text { Et ait Jesus: Beátus es, Simon Petre, } \\
\text { quia caro et sanguis non revelávit tibi, } \\
\text { sed Pater meus, qui es in cælis. }\end{array}$ & $\begin{array}{l}\text { Whom do men say that the Son of Man is? } \\
\text { Peter answered and said: } \\
\text { Thou art Christ, the Son of the living God. } \\
\text { And Jesus said: Blessed art thou, Simon } \\
\text { Peter, } \\
\text { because flesh and blood have not revealed it } \\
\text { to thee, } \\
\text { but my Father, who is in heaven. }\end{array}$ \\
\hline
\end{tabular}

The motive of the first section of the Motet is first sung by the tenor.

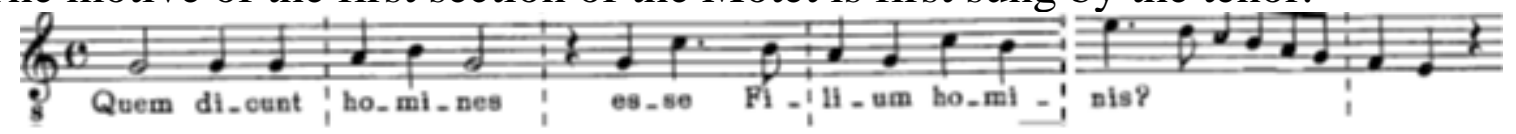

Richafort, Motet Quem dicunt homines

The four voices, superius, altus, tenor and bassus, enter successively as imitation, sometimes slightly modifying the original motive. Elsewhere the voices sing in free counterpoint.

II. Motete Quem dicunt homines

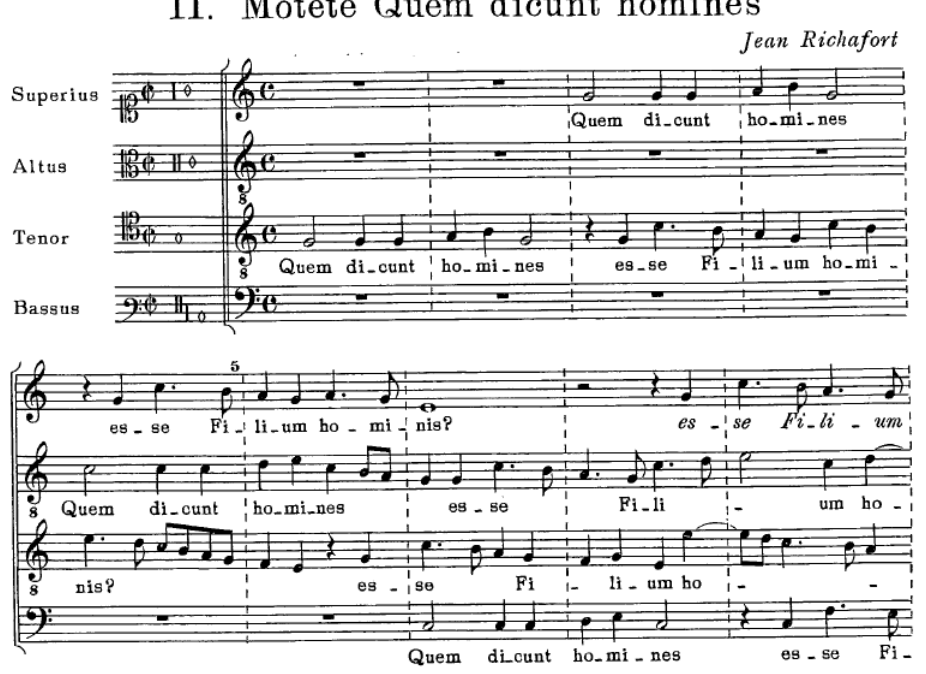

Richafort, Motet Quem dicunt homines

Many musicians composed Masses on Richafort's Motet. Among them there are Jean Mouton (ca. 1459 - 1522) and Antonius Divitis (ca. 1475 - 1530), who may have written their Quem dicunt homines Masses for the meeting of Francis I of France and Pope Leo X, which took place in Bologna in 1515. 
Missa Quem dicunt homines

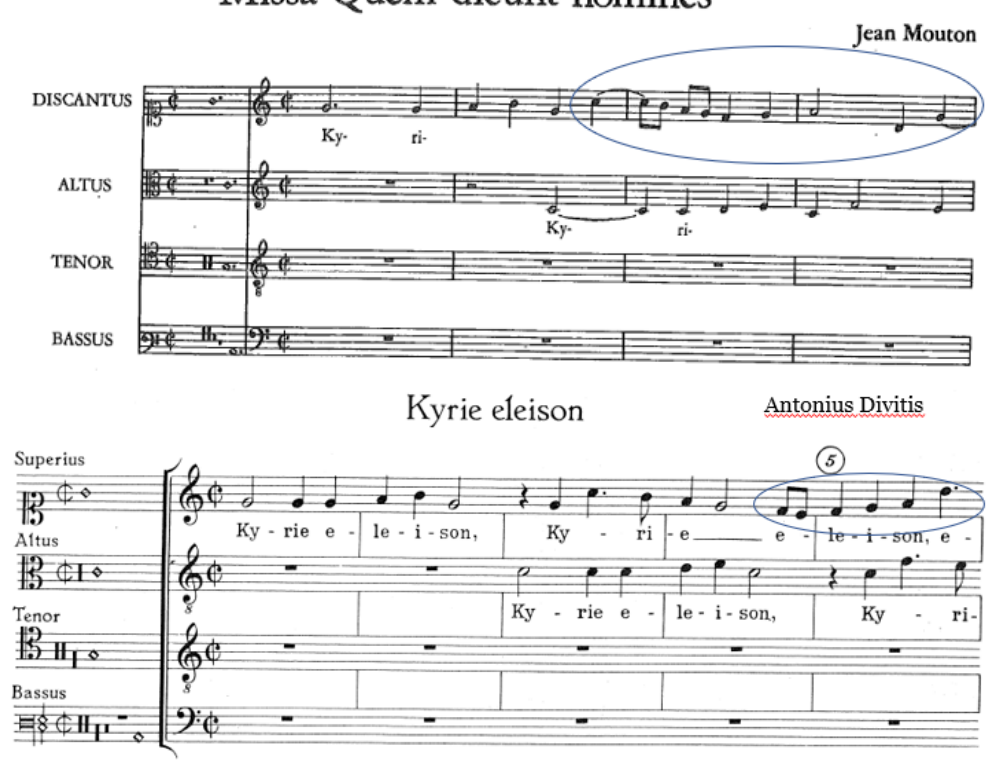

Fig. 2, Kyrie by Mouton and Divitis. The highlighted sections stress the modifications of the original motive

As we can see, Richafort's motive has been slightly changed rhythmically and/or melodically. Among the composers who wrote parody Masses on Quem dicunt homines there are also Cristòbal de Morales (ca. 1500 - 1553), who likely composed all his Masses in the period he spent in Rome (1535-1545), and Giovanni Pierluigi da Palestrina (1525-1594).

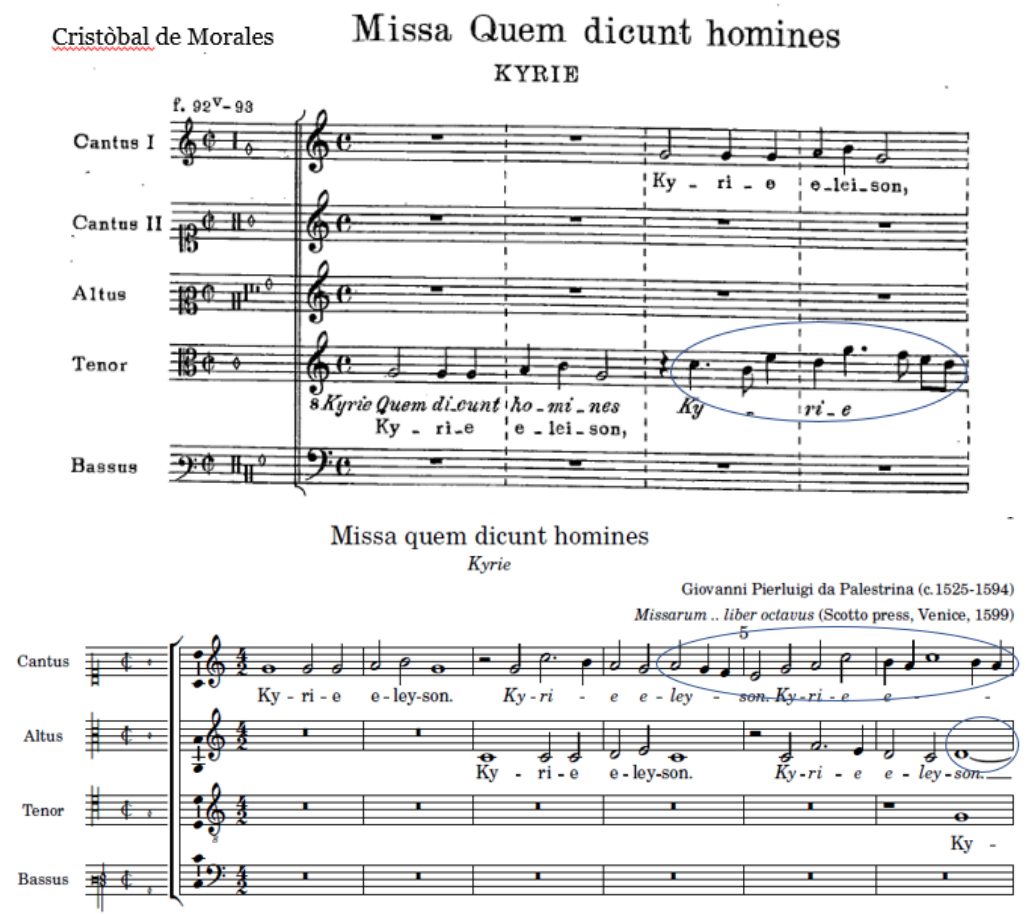

Fig 3, Kyrie by Morales and Palestrina. The highlighted sections stress the modifications of the original motive

It is well-known that, although Palestrina wrote also paraphrase, cantus firmus, "free", canonic, and alternatim Masses, his preference was for the parody Mass. His fifty-one works of this genre for sure reflect his own taste, but also the prevailing taste of the Roman church circles where he enjoyed his successful 
career (Atlas, 2006). The methods of imitation the composer used in composing the Mass Ordinary, that is the part of the Mass that is constant in the liturgical year, could vary. Variations can be thought of as being along a continuum that goes from breaking up the model into different sections, freely modifying them and alternating them with original sections (Sorce Keller, 2012), to taking the entire music of the Motet, simply replacing its text with the text of the Mass. In Palestrina's Mass Quem dicunt homines all three sections of the Kyrie present some variations to the motives of the Motet: so does the Kyrie I,

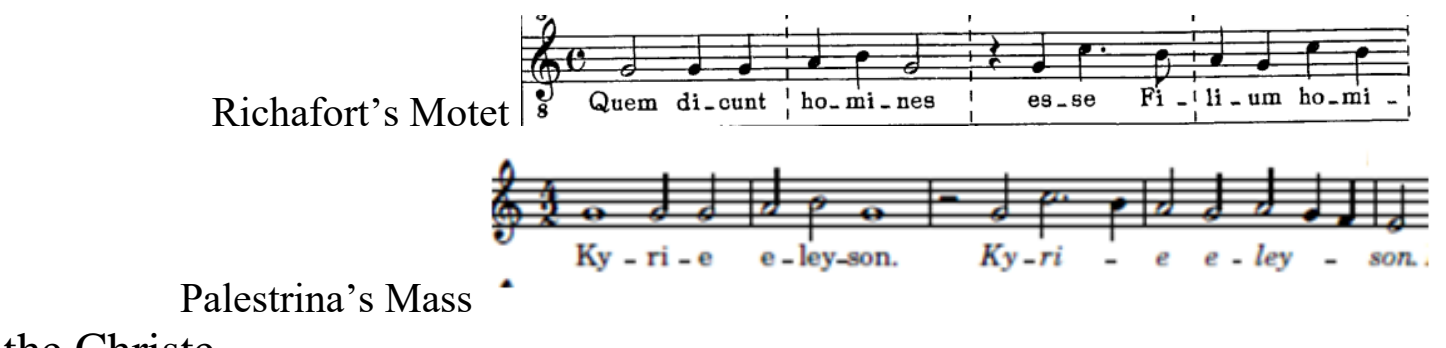

the Christe,

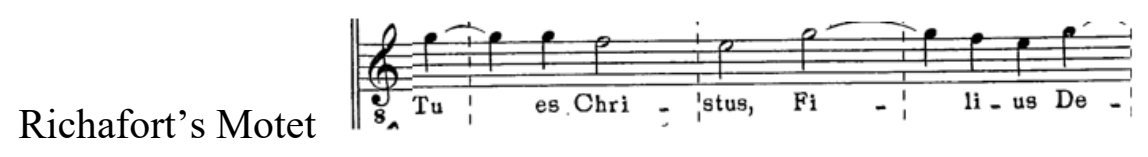

and the Kyrie II
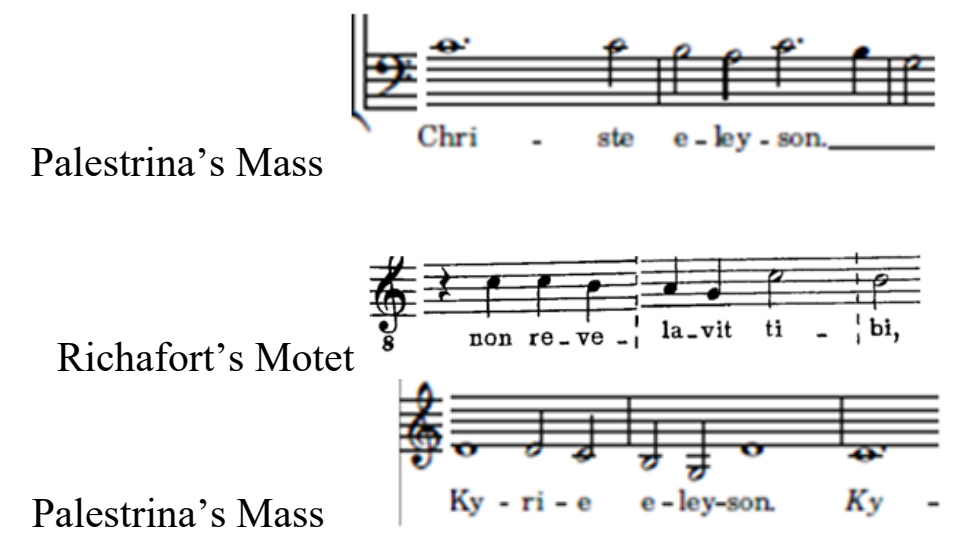

Indeed, the most important peculiarity of the parody Mass is what differentiates it from a cantus firmus composition. In the latter, the motive borrowed closely matches the original one, whereas in the former the borrowed motives are developed much more freely, according to the principles of imitation and emulation characterizing Renaissance rhetoric (Carrozzo and Cimagalli, 1997). For this reason, it is interesting to briefly mention the main peculiarities of the thought on rhetoric endorsed in the Renaissance.

\section{Two schools of thought: which role for imitation in the artists' education?}

The Italian Renaissance saw the rebirth of classicism and the reiteration of classical themes and styles in literature, rhetoric and visual arts: poets such as Petrarca and Boccaccio, and visual artists, such as Michelangelo, took inspiration from Greek and Latin poetry and sculpture, imitating and emulating their models (Lummus, 2012). The works of ancient Latin and Greek poets, philosophers and artists were considered an essential part of culture, and the imitation of earlier works and the number of writings by Renaissance scholars focusing on this theme are among the most interesting characteristics of this period's literature, rhetoric and the arts (Gmelin, 1932). 
Indeed, the diplomat and philosopher Niccolò Machiavelli (1469-1527) wrote in the introduction of his Discourses on the First Ten Books of Titus Livy that the whole Italian Renaissance civilization could be termed "a culture of imitation" (Pedullà, 2010: 736). It is not by chance that during the Renaissance imitation was considered a pedagogical method, establishing a set of rules for educating public speakers in formation (Girardi, 2020).

The theme of imitation has been developed by many renowned intellectuals and philosophers, such as Poliziano, Bembo, Pico and Cortesi. Their writings on imitation spread throughout Europe, being the object of intense scholarly debate for hundreds of years, and can offer us guidance for the interpretation of specific peculiarities characterizing not only Renaissance literature, but also its music (Pigman, 1979). Contemporary experts centering their studies on the Renaissance recognize two major schools of thought: the one, which includes Vida, Calcagnini and Cortesi, recommended the highest level of adherence to the chosen models. The other, encompassing Petrarca, Pico della Mirandola, Bembo, Erasmus, and Poliziano, endorsed imitation without losing individuality.

The humanist, bishop and poet Marco Gerolamo Vida (1485-1566) conceived imitation as a highly desirable theft and suggested to imitate "the words themselves" used by renowned orators (Pigman, 1979: 17). The humanist and scientist Celio Calcagnini (1479-1541) observed that, in order to make substantial progress, it is necessary to contend with contemporaries and with the silent teachers and masters of the past, whose teachings allow us to cease to be "speechless children" (Pigman, 1979: 20). The Apostolic Secretary Paolo Cortesi (1471-1510) equated those who reject imitation with the aim of favoring originality to someone who wanders aimlessly, unwittingly bearing the risk of losing his path and landing in bramble bushes (Pedullà, 2010).

On the contrary, already Francesco Petrarca (1304-1374), a poet and scholar who lived during the early Renaissance, stressed that imitation should seek for similarity rather than sameness, and that an author should preserve his artistic autonomy even in using other people's models (McLaughlin, 1995). Gianfrancesco Pico della Mirandola (1469-1533) suggested to expose students to a wide spectrum of authors but to allow them to maintain their own voices (Greene, 1982). Pietro Bembo (1470-1547) proposed that orators in formation should at first imitate their models, then strive to overtake them and finally devote their effort to surpass them (Scott, 1991). Desiderius Erasmus Roterdamus (1466-1536) maintained that imitators should in any case be aware of the differences existing between their times and the past, and should therefore strive to adapt the style of ancient authors to the present time (Pigman, 1979). Angelo Poliziano (1454-1494) supported the view that borrowing in itself was not sufficient to produce real artworks, and should therefore always be combined with the original inspiration of the artist (Pedullà, 2010).

\section{Some reflections and conclusive remarks}

As highlighted in the previous sections, during the Renaissance the pedagogical theory of imitation has been applied to rhetoric, poetry, music and the visual arts. Musicians wishing to compose Masses had a number of options. 
Among them, those composers who sustained the appropriateness to accurately follow the model of an earlier work, very likely composed cantus firmus Masses. On the contrary, composers striving to imitate and then emulate the achievements of other musicians, very likely composed parody Masses. However, in both cases, composers cited one or more musical motives created by another musician. This can be considered as a means to pay tribute to the composer whose work they took as a model, master the composing techniques shown therein, increase their own expertise and attain proficiency in making well-composed works.

Can current music pedagogy draw some suggestions about how appropriate it is to encourage students to imitate the style of an earlier performance or composition? Since the 1970s some scholars maintained that imitation jeopardizes creativity: Richard Boyd viewed the teacher-as-model relationship as inherently authoritarian (Boyd, 2001) and Janine Rider argued that imitation promotes mechanical and deadly composing (Rider, 1990). However, other scholars suggest that the student who imitates becomes free "from the inhibiting anxiety of striving for correct form and appropriate style" (Gorrell, 1987: 58) and, more generally, free "from the obligation of evolving new developments" (Corbett, 1980: 81), avoiding the painful and clumsy searching for ideas often characterizing novice composers (D’Angelo, 1973). Indeed, in some experts' view, learning is more a matter of imitation than a matter of invention (Bartholomae, 1985), and the students' originality can be enriched and developed from "a familiarity with originality in the works of others" (Weathers and Winchester, 1969: 2).

Concluding, a cautious use of imitation can be an effective pedagogical tool in the education of both composers and performers. It is obviously up to the teacher to promote the students' autonomy, pushing them to rely less on imitation and more on their own capacities, resources and commitment, the more capable and competent students become.

\section{References}

1. Atlas Allan W., (2006), Music for the Mass, in James Haar (ed.) European Music 1520-1640, The Boydell Press, Suffolk, 101-129

2. Bandura Albert and Robert W. Jeffrey, (1973), Role of symbolic coding and rehearsal processes in observational learning, in "Journal of Personality and Social Psychology", 26, 122-130.

3. Bartholomae David, (1985), Inventing the University, in Mike Rose, When a Writer Can't Write: Studies in Writer's Block and Other Composing Process Problems, Guilford, New York, 273-285

4. Boyd, Richard, (1991), Imitate Me, Don't Imitate Me: Mimeticism in David Bartholomae's 'Inventing the University', in "Journal of Advanced Composition" 11(2), 335-345

5. Carrozzo Mario and Cristina Cimagalli, (1997), Storia della musica occidentale, 3 vols., Armando, Roma

6. Corbett Edward P.J., (1980), Ventures in Styles, in Aviva Freedman and Ian Pringle (eds.), Reinventing the Rhetorical Tradition, L \& S Books, Conway, 79-87

7. D'Angelo Frank, (1973), Imitation and style, in "College Composition and Communication", 24(3), 283-290.

8. Lummus David, (2012), Boccaccio's Hellenism and the Foundations of Modernity, in "Mediaevalia" vol 33, 101-167 
9. Dumont Hanna, (2018), Adaptive teaching: Students' differences and productive learning, in OECD, Understanding Innovative Pedagogies: Key Themes to Analyse New Approaches to Teaching and Learning, OECD Education Working Paper No. 172, Paris, 13-32

10. Girardi Chiara, (2020), Imitation and Mimesis in the Renaissance, in Marco Sgarbi, Encyclopedia of Renaissance Philosophy, Springer Nature, 2020, 1-11

11. Gmelin Hermann, (1932), Das Prinzip der Imitatio in den romanischen Literaturen der 40 Renaissance, in "Romanische Forschungen" 46, 83-360.

12. Gorrell Donna, (1987), Freedom to Write-Through Imitation, in "Journal of Basic Writing" 6.2, 53-59.

13. Greene Thomas M., (1982), The Light in Troy: Imitation and Discovery in Renaissance Poetry. Yale University Press, New Haven and London

14. Günther Ursula, (1986), Citazione e modello nella musica del XIV secolo, in F. Alberto Gallo (a cura di), Musica e storia tra Medio Evo e Età moderna, Bologna, Il Mulino, 143-148

15. Lockwood Lewis, (1964), A view of the early sixteenth-Century Imitation Mass, in Albert Mell (ed.),Twenty-fifth Anniversary Festschrift, New York: The Department of Music, Queens College of the City of New York, 53-77

16. Sorce Keller Marcello, (2012), What Makes Music European. Looking Beyond Sound, The Scarecrow Press, Lanham-Toronto-Plymouth

17. Mayer Brown Howard, (1986), Imitazione e modello nella musica del XV secolo, in F. Alberto Gallo (a cura di), Musica e storia tra Medio Evo e Età moderna, Bologna, Il Mulino, 149-160

18. McLaughlin Martin L., (1995), Literary imitation in the Italian renaissance. The theory and practice of literary imitation in Italy from Dante to Bembo, Clarendon Press, Oxford

19. Oliver Mary, (1994), A Poetry Handbook: A Prose Guide to Understanding and Writing Poetry, A Harvest Original, Harcourt, San Diego-New York-London

20. Pedullà Gabriele, (2010), Sulle tracce degli antichi?, in Sergio Luzzatto, Gabriele Pedulla', and Amedeo De Vincentiis (eds.), Atlante della letteratura italiana, vol. I, Dalle origini al Rinascimento, Einaudi, Torino, 732-738

21. Peterson Amelia, (2018), The purpose of pedagogy, in OECD, Understanding Innovative Pedagogies: Key Themes to Analyse New Approaches to Teaching and Learning, OECD Education Working Paper No. 172, Paris, 8-12

22. Pigman George W. III, (1979), Versions of Imitation in the Renaissance, 1979, https://authors.library.caltech.edu/39490/1/HumsWP-0037.pdf, accessed 11.10.2020

23. Rider Janine, (1990), Must imitation be the mother of invention, in 9.2 "Journal of Teaching Writing" 9.2, 175-185

24. Russell Dale A., (1979), De imitatione, in David West and Tony Woodman (eds.), Creative Imitation and Latin Literature, Cambridge University Press, Cambridge, 1-16

25. Scott Izora, (1991), Controversies over the imitation of Cicero in the Renaissance, Hermagoras Press, Davis

26. Smith Frank, (1986), Insult to Intelligence the Bureaucratic Invasion of Our Classrooms, Arbor House, New York

27. Weathers Winston and Otis Winchester, (1969), Copy and Compose: A Guide to Prose Style, Prentice-Hall, Englewood Cliffs

28. Zielonka Barbara Anna, (2019), Keys to Educational Success: The Teaching Methods of a Top 10 Finalist of the Global Teacher Prize 